\title{
Dietary Fibre Content in Healthy Millet Based Recipes
}

\author{
M. Mounika* and K. Uma Devi \\ Department of Foods Nutrition, College of Home science, Post Graduate and Research \\ Centre Professor Jayashankar Telangana State Agriculture University - Hyderabad, India \\ *Corresponding author
}

K e y w o r d s
Pearl millet
(Pennisetum
glaucum), Finger
millet (Eleusine
coracana), Kodo
millet (Paspalum
setaceum)

A B S T R A C T

The present study was undertaken to analyse the dietary fibre content of millets and millets recipes. Dietary fibre from millets binds cholesterol and does not allow it to be absorbed, thus protect from heart diseases. Among all millets, foxtail millet had the highest content of dietary fibre $11.24 \mathrm{~g} / 100 \mathrm{~g}$. Dietary fibre content of millet dosas ranged between $14.1 \mathrm{~g}$ and $21.0 \mathrm{~g}$, highest in proso millet dosa and lowest in finger millet dosa and compared to rice dosa all millets had higher dietary fibre content. In millet idlis, dietary fibre content was minimum with $11.8 \mathrm{~g}$ in sorghum and maximum $23.3 \mathrm{~g}$ in proso millet idli, just like in dosas and dietary fibre of rice idli was close to finger millet idli. Dietary fibre content of millet rotis was minimum with $5.7 \mathrm{~g}$ in sorghum roti and maximum in foxtail millet roti $(14.0 \mathrm{~g})$ and when compared, wheat roti had least $(3.8 \mathrm{~g})$ dietary fibre. In millet meals, dietary fibre ranged between 5.8 to $14.0 \mathrm{~g}$, with lowest in sorghum and highest in foxtail millet meal and when compared to millet meals, rice meal had the lowest dietary fibre content. Millet dosa and idlis had better dietary fibre followed by millet meals and least being in rotis.

\section{Introduction}

Millets are small-seeded grains often known as coarse cereals. Different varieties of millets are grown such as pearl millet (Pennisetum glaucum), finger millet (Eleusine coracana), Kodo millet (Paspalum setaceum), proso millet (Penicum miliaceum), foxtail millet (Setaria italica), little millet (Panicum sumatrense), and sorghum (Sorghum bicolor) (Bouis, 2000; Kaur et al., 2012). Millet offers both nutritional and livelihood security for human beings and also feed security for diverse livestock populations in dryland regions of rural India (Pradhan et al., 2010).

Each one of the millets has more fibre than rice and wheat, some having fifty per cent higher than that in rice. Consumption of dietary fibre lowers blood glucose levels and helps to maintain normal levels and promote dietary management of type II diabetics. 
Millet fibre due to its incomplete or slow fermentation by microflora in the colon, promotes normal laxation which prevents constipation, diverticulosis and diverticulitis. Nowadays children, adolescents, adults including older people are facing constipation problem regularly due to excess intake of refined food. Through millet-based foods it is possible to reduce the problem of constipation.

Along with nutrition millets offer health benefits in the daily diet and help in the management of disorders like diabetes mellitus, obesity, hyperlipidemia, etc. Millets offer a unique advantage for health being rich in micronutrients, particularly minerals and $\mathrm{B}$ vitamins as well as nutraceuticals.

\section{Nutritional value of millets}

Millet grains are the storehouses of many chemical components including nutrients, phytochemicals and non-nutritive plant protective functional constituents. The nutritive value of millets is comparable to other cereals with slightly higher contents of protein and minerals, on an average millet contain $10 \%$ protein and $73 \%$ carbohydrate (Gopalan et al., 2009). Millets are rich in BVitamins (especially niacin and B6), calcium, iron, potassium, magnesium and zinc. They are generally low in lysine (amino acid) and must be used along with foods that are rich in lysine to balance the protein in the diet (Lonnerdal et al., 2000). While millet protein is superior to that of wheat or corn in terms of essential amino acids, it contains less than half the amount of the essential amino acid lysine that is found in high-quality protein sources such as meat.

The general properties of foxtail millet oil and its fatty acid profile. It was revealed that it is a good source of natural oil rich in linoleic acid and tocopherols (Liang and Yang, 2010; Amadou et al., 2011).
Adekunle et al., 2012; Yang et al., 2012; Obilana et al., 2002 reported that millet has many nutritious and medicinal functions and it is a drought resistant crop could be stored for a long time without insect damage; hence, very important during a famine.

Nutrition reviews, 2009 reported that sorghum contained $10.4 \mathrm{~g}$ protein, $1.9 \mathrm{~g}$ fat and around $8.3 \mathrm{~g}$ total dietary fibre per $100 \mathrm{~g}$ grain. Most of the fibre was present in the pericarp and cell walls, $4.1 \mathrm{mg}$ of iron, $6.5-7.9 \mathrm{~g}$ insoluble fibre and $1.1-1.2 \mathrm{~g}$ soluble fibre. Insoluble dietary fibre increased during food processing due to increased levels of bound protein mainly kafirins, and enzyme-resistant starch.

The crude fibre content reported in Kodo millet was $6.3 \mathrm{~g}$ per cent followed by little millet and proso millet with $5.51 \mathrm{~g} \%$ and $5.73 \mathrm{~g} \%$ respectively.

Thus, minor millets were known to be good storehouses of nutrients with varietal differences evident within the species (Kulkarni et al., 1992).

\section{Materials and Methods}

The selected millets namely finger millet, pearl millet, little millet, foxtail millet, proso millet and sorghum were processed and developed into two meal items i.e. millet rice and roti and two breakfast items namely idly and dosa. As control rice was used for idli, dosa, boiled rice and wheat was used for making roti. Basic standard preparations procedures were followed for all millet preparations.

\section{Preparation}

The millets selected for the study were, finger millet (Eleusine coracana), Foxtail millet (Setaria italica), pearl millet (Pennisetum glaucum), sorghum (Sorghum vulgare), little 
millet (Panicum milliare), and proso millet (Panicum miliaceum) which were some of the most important cultivated and consumed species some five to six decades back in the states of Andhra and Telangana regions of India. The millet grains were procured from Grameenmall Foundation, Hyderabad, a NonGovernment Organization that encourages the farmers to cultivate millets and formed them into cooperative groups.

Raw grains of the selected millets were analysed for the proximate nutrients and mineral composition from the edible portion of each grain. Pearl millet, finger millet and sorghum were edible without dehulling, whereas, foxtail millet, little millet and proso millets were dehulled to make them edible.

The selected millets were cooked to make four recipes. Two breakfast items namely idli and dosa and two meal items namely boiled millet (rice) and roti.

The idea of processing of millets into food preparations like millet rice, rotis, idli and dosa involving boiling, pan roasting, soaking and grinding to batters and then steaming or shallow frying methods was to see if these processes have any influence on nutritional composition and nutrient availability.

\section{Estimation of Dietary fibre}

The dietary fibre content was determined by the rapid enzymatic method (Asp, 1987)

\section{Results and Discussion}

The moisture content of foxtail millet flour and rice flour was 9.35, and $11.91 \%$ respectively. Foxtail millet showed significantly lower moisture content than rice. No significant difference was found between the moisture content of barnyard millet and rice flour.

\section{Dietary fibre content of millets}

Among all millets, finger millet had the highest content of dietary fibre $11.24 \mathrm{~g} / 100 \mathrm{~g}$ and the decreasing order of dietary fibre in millets was $11.24 \mathrm{~g}$ in foxtail millet, $11.0 \mathrm{~g}$ in pearl millet, $9.7 \mathrm{~g}$ in sorghum, $9.1 \mathrm{~g}$ in proso millet and $7.0 \mathrm{~g}$ in little millet. Foxtail millet and finger millet had dietary fibre values close to each other and a similar trend was seen between the dietary fibre content of proso millet and sorghum which was close to each other.

Though foxtail millet was dehulled to make it edible, the fibre content was high and was on par with finger millet. Proso millet also showed a good amount of dietary fibre of $9.1 \mathrm{~g}$ in spite of dehulling. Little millet, owing to its small size and low surface further due to dehulling was found to have proportionately less difference compared to the rest of the millets.

Consumption of dietary fibre lowers blood glucose levels and helps to maintain normal levels and promote dietary management of type II diabetics. Dietary fibre from millets binds cholesterol and does not allow it to be absorbed, thus protect from heart diseases. Millet fibre due to its incomplete or slow fermentation by microflora in the colon, promotes normal laxation which prevents constipation, diverticulosis and diverticulitis.

Dietary fibre of rice and wheat 3.2 and $10.1 \mathrm{~g}$, rice has lower dietary fibre compared to millets. The insoluble dietary fibre constituted the major portion of total dietary fibre in finger millet. The bran rich fraction of finger millet contained high insoluble dietary fibre, which ranged between $54 \mathrm{~g}$ to $72 \mathrm{~g} / 100 \mathrm{~g}$ (Krishnan et al., 2012).

The health benefits associated with high fibre foods are delayed nutrient absorption, 
increased faecal bulk, lowering of blood lipids, prevention of colon cancer, a barrier to digestion, mobility of intestinal contents, increased fecal transit time and ferment ability characteristics (Tharanathan and Mahadevamma, 2003).

\section{Dietary fibre in millet recipes}

The dietary fibre content in millet dosas followed the increasing order from sorghum dosa with $6.8 \mathrm{~g}$ to finger millet dosa with $14.1 \mathrm{~g}$, pearl millet dosa with $14.2 \mathrm{~g}$, little millet dosa with $15.5 \mathrm{~g}$, foxtail millet dosa with $20.2 \mathrm{~g}$ and proso millet dosa with $21.0 \mathrm{~g}$ per 100g. Traditional rice based dosa had $7.5 \mathrm{~g}$ dietary fibre, which was lower than all millet dosas except sorghum dosa. Foxtail millet dosa and proso millet dosa had closer dietary fibre values and finger millet dosa and pearl millet dosa had similar values of dietary fibre content.

Rice idly had the least dietary fibre of $7.6 \mathrm{~g}$ compared to all millet idlis. Dietary fibre was highest in proso millet idli with $23.3 \mathrm{~g}$ followed by foxtail millet idli with $22.8 \mathrm{~g}$, finger millet idli with $20.8 \mathrm{~g}$, pearl millet with $19.7 \mathrm{~g}$, little millet idli with $17.5 \mathrm{~g}$ and least in sorghum idli with 11.8g per 100g (Table 1).

Table.1 Dietary fibre content of millet recipes

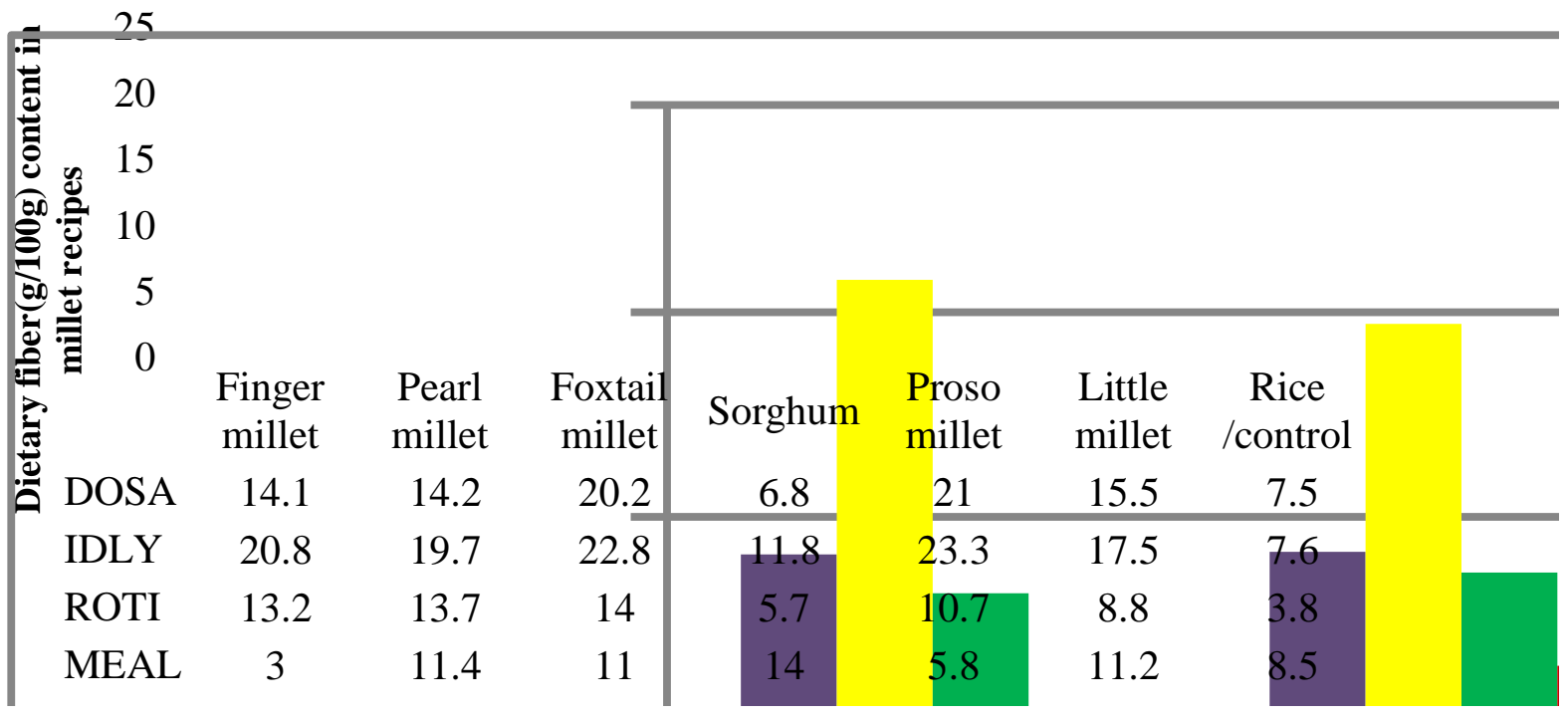

Dietary fibre of control wheat roti was $3.8 \mathrm{~g}$, which was the least of all rotis. The dietary fibre content of millet rotis was followed by $13.2 \mathrm{~g}$ in finger millet roti and in the increasing order of rotis, $13.7 \mathrm{~g}$ in pearl millet roti, $14.0 \mathrm{~g}$ in foxtail millet roti, 5.7gin sorghum roti, $10.7 \mathrm{~g}$ in pro so roti and $8.7 \mathrm{~g} / 100 \mathrm{~g}$ in little millet roti.

On an overall basis, the dietary fibre content of all millet in all 4 preparations was high compared to control rice and wheat preparations. Next to the control samples, sorghum idli, rice and roti had lower dietary fibre content because dehulled sorghum grain, semolina and flour were used for the preparations. Compared to other millet preparations foxtail millet preparations had higher dietary fibre content, followed by proso millet and then by finger millet and pearl millet preparations. Though foxtail millet and proso millet were dehulled to make them, edible they still had higher dietary fibre compared to others. Finger and pearl millet 
also had higher dietary fibre because they were not dehulled.

Dietary fibre was high in millet breakfast items idli and dosa, along with control rice based idli, dosa and raw millets in spite of the processing steps like soaking, grinding, fermentation and steaming. Whereas, the boiling method and roasting method had a slight rise compared to raw samples.

The dietary fibre content was slightly increased in millet recipes. Among the millet recipes highest dietary fibre content was found in foxtail millet idly, followed by proso millet dosa. Remaining millet products have a low content of dietary fibre. The low dietary fibre content in rice products, sorghum meal and all other millet products had lower than foxtail and proso millet recipes.

Since the millet recipes were normally prepared from the whole meal, the dietary fibre, minerals, phenolics and vitamins concentrated in the outer layer of the grain or the seed coat form part of the food and offered their nutritional and health benefits. When the millet was processed to separate out the seed coat matter as is normally done in millet malting and milling, it could be used as an adjunct in special food applications (Malleshi and Klopfentein, 2003).

Dietary fibre was high in millet breakfast items idli and dosa, along with control rice based idli, dosa and raw millets in spite of the processing steps like soaking, grinding, fermentation and steaming. Whereas, the boiling method and roasting method had a slight rise compared to raw samples.

\section{References}

Adekunle, A.A. Ellis-Jones, J., Ajibefun, I., Nyikal, R.A., Bengali, S., Fatunbi, O and Ange, A. 2012. Agricultural innovation in sub-Saharan Africa experiences from multiple stakeholder approaches. Forum for Agricultural Research in Africa, Ghana. ISBN 9789988- 837320 -837324.

Amadou, I., Gbadamosi, O. S and Wei, L.G. 2011. Millet based traditional processed foods and beverages-A review. Cereal Food World. 56(3): 115-121.

AOAC. 2005. Official Methods of analysis for Moisture. Association of Official Analytical Chemist. $18^{\text {th }}$ Ed. Arlington VA 2209.

Bouis, H. E. 2000. Enrichment of food staples through plant breeding: a new strategy for fighting micronutrient malnutrition. Journal of Nutrition. 16: 701-704.

Gopalan, C., Rama Sastri, B.V and Balasubramanian, S.C. 2009. Nutritive Value of Indian Foods. Hyderabad. India, NIN, ICMR.

Kaur, K.D., Jha, A., Sabikhi, L and Singh, A.K. 2012. Significance of coarse cereals in health and nutrition: a review. Journal of Food Science Technology. 51(8): 1429-1441.

Krishnan, Usha, D., Nagappa, G and Malleshi, L.W.T. 2012. Influence of decortication, popping and malting on bioaccessibility of calcium, iron and zinc in finger millet. Food Science and Technology. 48(2): 169-174.

Kulkarni, L.R., Naik, R.K. and Katarki, P.A, 1992. Chemical composition of minor millets. Karnataka Journal of Agricultural Science. 5 (3): 255-258.

Liang, S and Yang, Y.M. 2010. Chemical characteristics and fatty acid profile of foxtail millet bran oil. Journal of the American Oil Chemists Society. 87: 6367.

Lonnerdal, B. 2000. Dietary factors influencing zinc absorption. Journal of Nutrition.130: 1378-1383.

Mallesh, N.G and Klopfentein, C.F. 2003. Nutrient composition and amino acid 
contents of malted sorghum, pearl millet and finger millet and their milling fractions. Journal of Food Science and Technology.

Obilana, A. B and Manyasa, E. 2002. Millets. In: Belton, P. S. and Taylor, J. R. N (Eds.). Pseudo cereals and less common genetique du fonio (Digitaria exilis stapf) en Afrique de 1'Ouest, Conakry, Guinee, Rome (Italie) IPGRI. pp. 177217.

Pradhan, A., Nag and Patil, S.K. 2010. Dietary management of finger millet
(Eleusine coracana L. Gaerth) controls diabetes. International Journal of Current Science. 98(6): 763-765.

Tharanathan, R. N and Mahadevamma, S. 2003. Grain legumes a boon to human nutrition. Trends in Food Science Technolgy. 14(12): 507-518.

Yang, X., Wan. Z., Perry, L., Lu, H., Wang, Q., Hao, C., Li, J., Xie, F., Yu, J., Cui, T., Wang, T., Li, M and Ge, Q.H. 2012. Early millet use in northern China. Proceedings National Academy Sciences. 109(10): 3726-3730.

\section{How to cite this article:}

Mounika, M. and Uma Devi, K. 2019. Dietary Fibre Content in Healthy Millet Based Recipes. Int.J.Curr.Microbiol.App.Sci. 8(07): 1829-1834. doi: https://doi.org/10.20546/ijcmas.2019.807.217 